\title{
ERRATUM
}

\section{Systemic Air Embolism Following Manual Lung Inflation}

J.A. Tracey and V. Vartian

Can. Anaesth. Soc. J. 29: 272 May (1982)

Page 273, column 2, line 44 - "Hyperventilation" should read "Hyperinflation". 